\title{
Citation:
}

R.M. Willis, R.A. Stewart, P.R. Williams, C.H. Hacker, S.C. Emmonds, G. Capati (2011)

Residential potable and recycled water end uses in a dual reticulated supply system,

Desalination, 272(1-3), 201-211, doi:10.1016/j.desal.2011.01.022

Contact: r.stewart@griffith.edu.au

\section{RESIDENTIAL POTABLE AND RECYCLED WATER END USES IN A DUAL RETICULATED SUPPLY SYSTEM}

Willis, R.M., Stewart, R.A., Williams, P.R., Hacker, C.H., Emmonds, S.C., Capati, G.

\section{ABSTRACT}

The need to understand, model and predict urban water consumption is paramount, particularly with urban densities increasing throughout the world. Specifically, it is vital to determine potable water savings, daily demand patterns and actual end use water consumption experienced in diversified water supply schemes in order to verify planning estimates and justify the future application of such schemes. This paper details the results of a mixed methods (quantitative and qualitative) end use investigation, pre- and post-commissioning of recycled water, in a dual reticulated supply scheme in the master planned Pimpama Coomera region, Gold Coast, Australia. Recycled water, supplied for irrigation and toilet flushing, accounted for $59.1 \mathrm{~L} / \mathrm{p} / \mathrm{d}$ or $32.2 \%$ of total consumption post-commissioning, with irrigation being $28.9 \mathrm{~L} / \mathrm{p} / \mathrm{d}$ or $15.7 \%$. Furthermore, developed end use diurnal patterns demonstrate the unique daily demand consumption within the region and significant reductions in peak potable water demand when compared with single reticulated supply areas. The paper concludes with discussions of implications for better informed water services infrastructure planning activities.

Key words: diurnal patterns, dual reticulation, recycled water, water demand management, water end use 


\subsection{INTEGRATED URBAN WATER RESOURCES MANAGEMENT}

The provision of a secure supply of water for increasing populations in climate challenged regions is a critical issue. Australia is the world's driest inhabited continent with unpredictable rainfall patterns, hence the significant focus on conserving and sustainably managing the nation's already finite water supplies (Birrell et al., 2005, Commonwealth of Australia, 2008b). Queensland, an eastern state of Australia, has become increasingly hotter and drier, with trends indicating reduced rainfall of up to 50mm annually (Commonwealth of Australia, 2010, Anderson, 1996). This reduced rainfall trend is occurring over concentrated urban centres, where much of the nation's population resides, resulting in rainfall-dependent eastern Australian cities and towns having water supplies fall to record low levels over the past ten years (Commonwealth of Australia, 2008a, ABS, 2010). Traditionally, the supply of water for cities and towns placed a heavy reliance on dams, weirs or rivers but changing weather patterns and the growing urban population's water demands have necessitated a new approach (Barlow, 2009). Hence, Australia is now focussed on the development, planning and implementation of new water demand reduction initiatives to meet short-term water supply deficiencies and to manage long-term demand, together with supply augmentations including desalination (Turner et al., 2005, Webb, 2007, Barlow, 2009).

Integrated sustainable water resources planning and management has become a key driver of a raft of measures required to ensure future water demands are satisfied (WSAA, 2008). This sustainable water resources planning and management method involves the introduction and application of alternate supply options (such as desalination or recycling), water demand management measures (efficient devices, water restrictions and price controls) and source substitution initiatives (rainwater tanks, stormwater or recycled water), for a sustainable and secure source of water for future populations (Mitchell, 2006). The application of demand 
management and source substitution initiatives is widespread throughout the nation. However, the effective potable end use water savings which can be achieved by these measures is assumed or predicted and in almost all cases, and often remains unverified after application (Turner et al., 2007, Turner and White, 2006). The verification of effective water savings related to such initiatives is vital for the improvement of water services planning; for the accurate forecasting of water supply and demand and for strengthening the knowledge and application of such sustainable water management initiatives for the future (WSAA, 2003, WSAA, 2008).

\subsection{Water services planning}

Urban water demand forecasting used for the planning of water services infrastructure has been carried out for decades with consistent improvement occurring with the invention of new data collection techniques, analysis and modelling technologies. Predicting urban water demand requires an understanding of historical water services records, projected changes in demand patterns and system performance (DNRM, 2005). Water demand modelling elements, as detailed by WSAA (2003), include diurnal patterns, end use water consumption, peaking factors (maximum day, mean day maximum month and maximum hour), fire fighting parameters, system losses, non-revenue water and pressure parameters. These and other climatic, demographic and consumer influences are detailed in Figure A.1.

\section{[INSERT FIGURE A.1]}

Figure A.1 illustrates the influence of climate, water usage practices, water use equipment, demographics and land use, the water supply system and source substitution on water demand. While all elements presented in Figure A.1 are required for urban water forecasting, 
it is well documented that all too often 'demand forecasting studies have relied on projections of historical metered data without considering end uses' or by adopting end use data from different locations or countries (WSAA, 2003, pp. 6). Because household water consumption differs between countries, locations and populations, it is paramount that location specific end use data is utilised for local demand forecasting (Turner et al., 2005, Inman and Jeffrey, 2006). Giurco et al. (2008a) state that end use water consumption data is also required for the determination of actual potable water savings of alternative supply sources and water demand management initiatives. End use data assists in refining and validating the design assumption parameters that influence the planning of water services infrastructure (Gato, 2006). The advent of high resolution water meters and loggers along with affordable wireless communication technologies has enabled the dynamic, accurate measurement and data transfer of end use water consumption information (Stewart et al., 2010).

\subsection{Water end use and diurnal patterns}

Water end use studies provide data to assist in the determination of when, where and how residents consume water in the home (Giurco et al., 2008a, White, 2001). End use studies also offer 'significant opportunities for providers to improve water service delivery and long term planning' through the provision of detailed consumption data utilised for water demand predictions (Giurco et al., 2008a, pp. 1). The collection of end use data also assists with verification of other demand forecast factors including diurnal patterns and peaking factors like maximum day, mean day maximum month and maximum hour. Diurnal patterns demonstrate the demand or consumption across a day in hourly intervals. This pattern varies depending on the population, weather, the time of year, the day of the week (i.e. weekday versus weekends), season and residential consumption characteristics (Zhou et al., 2002). In Australia, end use water consumption studies have been undertaken in Perth and Melbourne, 
and most recently, the herein described investigation on the Gold Coast. Studies have been done in the USA and New Zealand. In Queensland, numerous bulk supplied diurnal patterns have been determined for forecasting total residential urban water use. However, end use water consumption and end use diurnal patterns for Queensland and for the Gold Coast are not available. Table A.1 details some of the more significant end use studies completed.

\section{[INSERT TABLE A.1]}

Loh and Coghlan (2003) undertook the first national end use investigation in Perth, Australia which detailed diurnal patterns from a total consumption level based on income, no end use diurnal patterns were published. The variability between indoor and outdoor consumption recorded in earlier end use studies is particularly prevalent when comparing Perth and Toowoomba (Table A.1). Outdoor consumption in Australian studies ranged from 18.6 litres per person per day $(\mathrm{L} / \mathrm{p} / \mathrm{d})$ in winter in the Gold Coast, $34 \mathrm{~L} / \mathrm{p} / \mathrm{d}$ Melbourne and $83.7 \mathrm{~L} / \mathrm{p} / \mathrm{d}$ in Perth. Indoor consumption also varied, with the Perth study recording $155 \mathrm{~L} / \mathrm{p} / \mathrm{d}$, the Melbourne study $169 \mathrm{~L} / \mathrm{p} / \mathrm{d}$, the Gold Coast study $138.6 \mathrm{~L} / \mathrm{p} / \mathrm{d}$ and the Toowoomba study recording just $122 \mathrm{~L} / \mathrm{p} / \mathrm{d}$. Roberts (2005) end use investigation covering Yarra Valley in Melbourne also detailed end use water consumption diurnal patterns for winter and summer use. In Roberts (2005) winter study, end usage peaked between 7 and 8am (9.1\% of total use), mostly due to showering, and between 6 to $7 \mathrm{pm}$ ( $6.9 \%$ of total use) due to a range of end uses in the home. Summer morning end use peaked between 7 and 8 am ( $8.3 \%$ of total use) while the evening peak occurred between to 9 to $10 \mathrm{pm}(10.3 \%$ of total use) due to significant irrigation usage (Roberts, 2005). While Mead's (2008) Toowoomba end use study was only from a small sample, end use diurnal patterns were detailed. Mead's (2008) highest peak occurred between 7 to $8 \mathrm{am}$ in the morning at 38 litres per household per day $(\mathrm{L} / \mathrm{H} / \mathrm{d})$ with the 
evening peak occurring between 5 to $6 \mathrm{pm}(32 \mathrm{~L} / \mathrm{H} / \mathrm{d})$. Shower usage was the highest end use contributor in both morning and evening peaks. Weekend data showed flatter and longer peak periods in the morning, with similar patterns for the evening. Clothes washing was an influential end use peaking factor on the weekends (Mead, 2008). The variability described between indoor, outdoor and diurnal consumption patterns determined through earlier end use studies prompted Giurco (2008a) and WSAA (2003) to encourage more research in this field. End use investigations into the effective water savings attributed to demand management and source substitution initiatives are required (Giurco et al., 2008b, WSAA, 2008).

The use of recycled water for specified end uses is well accepted as an effective and sustainable measure of water conservation and other schemes have been implemented throughout Australia (Marks and Zadoroznyj, 2005, Anderson, 1996, Po et al., 2005). The six schemes currently present throughout the nation include Rouse Hill (Sydney Water), Mawson Lakes (Adelaide), New Haven Village (Adelaide), Aurora (Melbourne), Marriott Waters (Melbourne) and the herein described Pimpama Coomera scheme (Gold Coast) (Willis et al., 2010a). All these schemes supply recycled water for toilet flushing and irrigation. These schemes were all premised on modelled predictions of end use and total potable water savings which could result from the application of dual reticulated recycled water. Predicted water savings ranged from $30-50 \%$ of the households' total demand (Hurlimann and McKay, 2006, Fearnley et al., 2004). Bulk supplied data have been recorded at Rouse Hill and New Haven Village with savings between 35-50\% found respectively (Sydney Water, 2008, Fearnley et al., 2004). Actual potable water savings for the other dual reticulated schemes are yet to be published. To date, no data have been published internationally on the actual water end use sourced from domestic potable and recycled service pipes within dual reticulated regions, nor has there been any verification of modelled end use diurnal demand patterns for these unique 
supply areas. Such field-collected end use data are necessary to improve forecasting, water services planning and to strengthen the application of similar schemes.

\subsection{Gold Coast's Pimpama Coomera dual reticulation scheme}

Gold Coast City is one of South East Queensland's major urban growth areas with the population predicted to grow from the current 0.5 million to 2.5 million people by 2056 (Po et al., 2005). This population expansion would trigger water consumption increases from the 2007 consumption of 185 megalitres per day (ML/d) $(\approx 48.87$ mega gallons (US) per day) to $466 \mathrm{ML} / \mathrm{d}$ by $2056(\approx 123.1$ mega gallons (US) per day) (GCW \& GCCC, 2007). With residents consuming $75 \%$ of the city's total yearly water supply in $2008 / 09$, considerable focus has been placed on reducing and managing residential water consumption in the city as well as reclaiming water and sourcing through desalination (capacity of Tugun Desalination Plant $125 \mathrm{ML} / \mathrm{d})$.

The PCWF Master Plan is the blueprint for sustainable integrated urban water management, for the Pimpama Coomera region of the Gold Coast, which is largely undeveloped and one of the fastest growing residential areas in Australia (Po et al., 2005). It stipulates the provision of sustainable water sources for a projected 150,000 people in 2056 (Pimpama Coomera region only) through the inclusion of dual reticulated recycled water, water conservation through water demand management (WDM) measures, rainwater tanks, stormwater management and smart sewers. The PCWF Master Plan region is Australia's first centralised dual reticulation distribution scheme for recycled water, providing Class A+ recycled water for approved end uses, which include toilet flushing and external irrigation (with the exception of filling pools and spas). Class A+ recycled water is the highest quality of recycled water for non-drinking purposes in the State of Queensland, Australia. It was predicted that between 30 to $40 \%$ of 
traditional communities' existing consumption could be substituted by recycled water. The introduction of rainwater tanks and water conservation measures would also reduce total potable water consumed in the PCWF Master Plan region (GCW, 2004).

The Pimpama Coomera (PC) End Use Study is a component of the wider Gold Coast Watersaver End Use (GCWSEU) Study which commenced in 2007 (Willis et al., 2009). The GCWSEU study was developed to investigate end use water consumption on the Gold Coast. Other objectives include establishing the effective end use savings attributed to dual reticulation and water demand management initiatives such as efficient and resource consumption awareness devices (Willis et al., 2010b). To date, there have been no end use investigations on dual reticulated recycled water schemes. Hence, the PC End Use Study was focused on establishing the end use water consumption, pre- and post-recycled water commissioning, and to determine savings attributed to a dual reticulated recycled water supply scheme (Willis et al., 2010a). The end use evaluation of a dual reticulated region is the first of its kind, both nationally and internationally.

The pre-commissioning Phase 1 component of the study was completed in 2009. The objectives of this phase as detailed by Willis et al. (2010a) included:

- Determine the recycled water pre-commissioning end uses for a statistically significant sample of PC households;

- Survey households participating in the end use study to determine demographics, attitudes, preferences and behaviours with respect to recycled water; and

- Predict the uptake of recycled water end uses and compare against actual end use break downs post-commissioning. 
Recycled water in the PC region is supplied through a separate recycled water pipeline for toilet flushing and irrigation; leakage also occurs on this line. Phase 1 of the PC End Use Study determined that toilet flushing behaviours would remain relatively similar but that irrigation would alter depending on a variety of factors such as water restrictions, recycled water pricing, climate and awareness campaigns. Phase 1 resulted in the development of a predictive uptake model of recycled water for the PC area based on these influencing factors. The predictive model calculated that the most likely total recycled water consumption postcommissioning would be 53 litres per person per day $(\mathrm{L} / \mathrm{p} / \mathrm{d})$ or $30.5 \%$ of total household consumption. Of this, toilet usage was $21.7 \mathrm{~L} / \mathrm{p} / \mathrm{d}$, leakage was $0.7 \mathrm{~L} / \mathrm{p} / \mathrm{d}$ and irrigation was $30.6 \mathrm{~L} / \mathrm{p} / \mathrm{d}$. The lower least likely estimates were $48 \mathrm{~L} / \mathrm{p} / \mathrm{d}$ or $28.4 \%$ with irrigation being 25.6 $\mathrm{L} / \mathrm{p} / \mathrm{d}$ and leakage and toilet usage remaining the same as the most likely estimate. The upper least likely estimate was $64.2 \mathrm{~L} / \mathrm{p} / \mathrm{d}$ or $34.7 \%$ recycled water use with $42.8 \mathrm{~L} / \mathrm{p} / \mathrm{d}$ for irrigation consumption and leakage and toilet usage remaining the same as the most likely estimate (Willis et al., 2010a). In December 2009, recycled water was supplied to the PC area. This triggered the commencement of Phase 2 of the PC End Use Study, namely the measurement of post-commissioning end use water consumption in the PC area. This paper details the results of Phase 2 of the PC End Use Study.

\subsection{OBJECTIVES AND SCOPE OF THE PAPER}

The objectives of Phase 2 of the PC End Use Study are:

- Determine the end uses for a statistically significant sample of PC households postcommissioning of recycled water using quantitative and qualitative data sources and analysis techniques;

- Compare dual (potable and recycled supply) and single (potable only) reticulated water supply schemes; 
- Undertake a comparison of measured recycled water consumption postcommissioning of recycled water in the PC region against the $\mathrm{PC}$ dual reticulation demand forecast model developed in Phase 1 of this study; and

- Develop a tool and investigate average daily diurnal demand patterns at an end use level for the PC dual reticulated region and the single reticulated control group.

This paper presents the results for the above stated objectives for Phase 2 of the study. To achieve the above stated objectives, a variety of collected quantitative and qualitative data sets and analysis techniques/tools were utilised including seasonal climatic data, bulk supply data, water end use data, qualitative water audits, questionnaire surveys and an end use diurnal pattern software tool. The method carried out to satisfy the objectives of Phase 2 of the study are summarised below:

1. Revalidate data collected through Phase 1 questionnaire survey, which obtained detailed descriptive information such as household occupants, resident age, family income, ownership status and education level;

2. Obtain seasonal climatic data and bulk supplied water consumption data for potable and recycled water for the duration of the study;

3. Utilise the sample of recruited households in the single and dual reticulated PC region from Phase 1 of the study to obtain actual end use water consumption from both the potable and recycled water lines. This data was collected utilising high resolution Actaris CTS-5 water meters (0.014 L/pulse) recording to DataCell D-CZ21020 data loggers at 10 second intervals;

4. Conduct end use analysis procedure using collected high resolution flow data inputted into Aquacraft's Trace Wizard(C) software, with the categorisation process aided by household stock inventory, qualitative household behaviour and descriptive data 
solicited from households sampled. The end use analysis quality assurance procedure detailed by Willis et al. (2010a) was adhered to, which included the use of qualitative water consumption behaviour data to identify and categorise water flow traces. Such qualitative information is critical for ensuring that flow trace data is accurately disaggregated into a registry of water end use events;

5. Compile the end use water consumption summaries for each household, which served as the post-commissioning end use data set;

6. Revisit the Phase 1 recycled water prediction model to compare the differences in actual post-commissioning end use consumption in the PC dual reticulated region.

7. Develop a diurnal pattern tool using 'Borland C Builder', which is a Microsoft (MS) Windows 'Multiple Document Interface' (MDI) compliant software. The 'Diurnal' program processes MS-Access data files produced by the auxiliary Trace Wizard $\mathbb{C}$ software with variable time series intervals ranging from hourly to five minute intervals; and

8. Undertake analysis using the 'Diurnal' tool for the collaboration of end use water consumption data across required time intervals for daily use.

For a comprehensive explanation of the methods undertaken to complete the GCWSEU study, readers are referred to Willis et al., (2009), Willis et al., (2010a) and Willis et al., (2010b). The results of the above described method are detailed below.

\subsection{PIMPAMA COOMERA END USE WATER CONSUMPTION STUDY}

\subsection{Pre-commissioning of recycled water to Pimpama Coomera region}

Phase 1 of the PC End Use Study identified factors reported to influence the uptake of recycled water. Climate was predicted to have the most significant impact on irrigation hence, 
an overview of climatic variables including rainfall and temperature and coinciding bulk recorded supply were summarised to establish appropriate periods to monitor end use water consumption post-commissioning (Figure A.2).

[INSERT FIGURE A.2]

Climatic trends shown in Figure A.2 follow sub-tropical patterns of high temperature and rainfall throughout summer and lower temperatures and rainfall in winter. Figure A.2 illustrates that the first pre-commissioning data collection period in winter 2008, occurred within an un-seasonally high rainfall period (Phase 1). This is reflected in both the city wide bulk supply and end use data being the lowest recorded over the study period. The summer pre-commissioning data log occurred in December 2008 when the Gold Coast city was under Queensland Water Commission (QWC) medium level restrictions of Target $200 \mathrm{~L} / \mathrm{p} / \mathrm{d}$. November 2008 experienced extreme rainfall of $440.6 \mathrm{~mm}$. This was the third highest rainfall month recorded on the Gold Coast between 2001 and 2010. December 2008 also experienced high rainfall volumes of $123.8 \mathrm{~mm}$. Understandably, bulk supplied residential consumption in December was low at $176.9 \mathrm{~L} / \mathrm{p} / \mathrm{d}$, with monthly consumption increasing to $196.3 \mathrm{~L} / \mathrm{p} / \mathrm{d}$ in January 2009. The total pre-commissioning end use water consumption in the dual and single reticulated regions, recorded in summer 2008/09, is detailed in Figure A.3. Single reticulated region use is presented in Figure A.3a, the dual reticulated region potable and recycled combined supply in Figure A.3b while, Figure A.3c and d present the dual reticulated regions potable and recycled supply lines separately.

[INSERT FIGURE A.3] 
The average summer pre-commission end use water consumption across the single and dual reticulated regions was recorded as $146.9 \mathrm{~L} / \mathrm{p} / \mathrm{d}(\mathrm{n}=127)$. Total consumption for the single reticulated region was $158.4 \mathrm{~L} / \mathrm{p} / \mathrm{d}$ (Figure A.3a) while the dual reticulated region was $9 \%$ lower at $143.5 \mathrm{~L} / \mathrm{p} / \mathrm{d}$ (Figure A.3b). The end use consumption volumes were relatively similar but just slightly lower in the dual reticulated region for shower, clothes washer, tap, toilet and dishwasher. In this data logging period, total irrigation consumption in the dual reticulated region was practically equal with the single reticulated region being $13.1 \mathrm{~L} / \mathrm{p} / \mathrm{d}$ (potable + recycled Figure A.3b) or 9\%, while the dual reticulated region was $12.7 \mathrm{~L} / \mathrm{p} / \mathrm{d}$ or $8 \%$ (Figure A.3a). In PC, irrigation on the recycled water line was just slightly lower than the potable water line, being $6.2 \mathrm{~L} / \mathrm{p} / \mathrm{d}$ for recycled versus $6.9 \mathrm{~L} / \mathrm{p} / \mathrm{d}$ for potable. This may have been due to the lack of community awareness programs encouraging the use of recycled for irrigation in the dual reticulated region at that time. Recycled line toilet use accounted for $21.9 \mathrm{~L} / \mathrm{p} / \mathrm{d}$ while leakage was $0.7 \mathrm{~L} / \mathrm{p} / \mathrm{d}$ (Figure A.3d). In the summer pre-commissioning phase, recycled water consumption accounted for $28.8 \mathrm{~L} / \mathrm{p} / \mathrm{d}$ or $20 \%$ of total end use in the dual reticulated region. Overall, other end uses (shower, clothes washer, tap, toilet etc.) were very similar in volumetric consumption across both regions. Clothes washer is slightly lower in the single reticulated region while shower consumption is slightly higher, compared to the dual reticulated region. Bathtub usage is higher in the dual than the single reticulated region (2.6 versus $1.4 \mathrm{~L} / \mathrm{p} / \mathrm{d}$ ) due to young children occupation. Leakage is also significantly higher in the single reticulated region $(13.0$ versus $2.0 \mathrm{~L} / \mathrm{p} / \mathrm{d})$ due to two single reticulated homes experiencing week long leakage during the monitoring period. This leakage volume is the reason for higher weekly average consumption in the single reticulated region. Overall, the total volumetric consumption in the single and dual reticulated regions was low due to high rainfall during the summer pre-commissioning data collection period. 


\subsection{Post-commissioning of recycled water to the Pimpama Coomera region}

As of the $1^{\text {st }}$ of December 2009, recycled water was supplied to the PC region, which triggered data collection for the summer post-commissioning period (i.e. Phase 2). The commissioning of recycled water was launched with an extensive awareness campaign promoting its supply and encouraging the use of recycled water in PC. Post-commissioning end use water consumption data was sampled over the summer 2009/10 season, identified as December 2009 to the beginning of March 2010. Two week data sets were taken from dissected samples over the season to account for seasonal affects (predominately rainfall) on irrigation usage. In total, the dual and single reticulated sample size was $n=100$ and $n=34$, respectively. During the post-commissioning collection periods, Gold Coast City was on QWC's permanent water conservation target level of $200 \mathrm{~L} / \mathrm{p} / \mathrm{d}$. Figure A.2 shows that the end use water consumption data collection period in December 2009, occurred when city wide bulk supplied water peaked to its highest level $(224.36 \mathrm{~L} / \mathrm{p} / \mathrm{d})$, while February and March 2010 had reduced bulk values due to lower temperatures and higher rainfall in these months (Figure A.2). Understandably, the irrigation end use category is the most variable and difficult to sample reliably. The strategy to collect end use data from a portion of households over the season serves to provide a mean irrigation volume for the sample in the season, but readers should note that irrigation end use values have much higher variance around the mean than indoor end uses. Figure A.4 illustrates the end use water consumption, postcommissioning of recycled water, in the single and dual reticulated regions. Single reticulated region use is presented in Figure A.4a, the dual reticulated region potable and recycled combined supply in Figure A.4b while, Figure A.4c and d detail the dual reticulated potable and recycled supply lines separately.

[INSERT FIGURE A.4] 
As discussed, the overall total water consumption increase from pre-commissioning in 2008 to post-commissioning 2010 data was due; to high rainfall in the 2008 logging periods, the capture of a record high consumption period in December 2009 and a gradual increase in total consumption across the study due to relaxed water restrictions and water conservation messages. Recycled water consumption post-commissioning in the $\mathrm{PC}$ region saw a significant increase of recycled water for irrigation purposes. Weather conditions during the post-commissioning period were generally dryer than those experienced in the precommissioning phase albeit both a high and low rainfall and consumption period of water use were captured. The average consumption post-commissioning of recycled water to the PC region was $183.6 \mathrm{~L} / \mathrm{p} / \mathrm{d}$ (Figure A.4b), a significant increase on pre-commissioning consumption of $143.5 \mathrm{~L} / \mathrm{p} / \mathrm{d}$ (Figure A.3b). Total consumption post-commissioning (183.6 $\mathrm{L} / \mathrm{p} / \mathrm{d}$ ) consisted of $59.1 \mathrm{~L} / \mathrm{p} / \mathrm{d}$ or $32.2 \%$ being consumed on the recycled water line and 124.5 $\mathrm{L} / \mathrm{p} / \mathrm{d}$ or $67.8 \%$ consumed on the potable line (Figure A.4b). Recycled water irrigation was $28.9 \mathrm{~L} / \mathrm{p} / \mathrm{d}$ and potable irrigation was $18.7 \mathrm{~L} / \mathrm{p} / \mathrm{d}$, both significantly higher than that recorded pre-commissioning. Recycled line toilet use and leakage were at $27.5 \mathrm{~L} / \mathrm{p} / \mathrm{d}$ and $2.7 \mathrm{~L} / \mathrm{p} / \mathrm{d}$ respectively (Figure A.4d), which is higher than recorded pre-commissioning. Other end uses remained similar to those experienced pre-commissioning with shower and clothes washer accounting for 43.3 and $28.9 \mathrm{~L} / \mathrm{p} / \mathrm{d}$ respectively (Figure A.4c). Overall, the major change in end use water consumption post-commissioning was in irrigation, with other end uses remaining similar pre-and post-commissioning of recycled water to the PC region.

Figure A.4a demonstrates that the single reticulated regions end use data varies somewhat from the dual reticulated region (Figure A.4b). Firstly, total consumption is only $171.9 \mathrm{~L} / \mathrm{p} / \mathrm{d}$, which was $11.7 \mathrm{~L} / \mathrm{p} / \mathrm{d}$ or $6 \%$ less than the dual reticulated region. Irrigation in the single 
reticulated region was $21.9 \mathrm{~L} / \mathrm{p} / \mathrm{d}$ which was similar to that recorded in PC on the potable line $(18.7 \mathrm{~L} / \mathrm{p} / \mathrm{d})$. Clothes' washing was slightly higher in the single reticulated region (36.9 versus 28.9 L/p/d) with shower usage also higher $(52.7$ versus $43.3 \mathrm{~L} / \mathrm{p} / \mathrm{d})$. Toilet usage was lower in the single reticulated region being $23.1 \mathrm{~L} / \mathrm{p} / \mathrm{d}$ compared with $27.5 \mathrm{~L} / \mathrm{p} / \mathrm{d}$ in PC. Tap, dishwasher and potable leakage were similar with bath use remaining higher in PC as has been the trend throughout the study duration. As a note to readers, toilet end use demand averages reported herein are more reliable and transferable to other schemes than irrigation. Irrigation end use demand averages can fluctuate from season to season and year to year due to localised climatic conditions (e.g. high rainfall summer reduces demand substantially) and are also less transferable to other regions with different climatic conditions.

\subsection{Comparison of Phase 1 prediction with Phase 2 data}

When comparing the results of Phase 2 of the PC End Use study (summer postcommissioning end use) with the recycled water uptake predicted in Phase 1 of the study (precommissioning prediction based on winter 2008 data) the actual recycled water end use falls between the most likely estimate, $53 \mathrm{~L} / \mathrm{p} / \mathrm{d}$ or $30.5 \%$ and the upper estimate of $64.2 \mathrm{~L} / \mathrm{p} / \mathrm{d}$ or 34.7\% (Willis et al., 2010a). The Phase 2 summer post-commissioning total recycled water usage was $59.1 \mathrm{~L} / \mathrm{p} / \mathrm{d}$ or $32.2 \%$ of total household end use (Figure A.4b and d). Postcommissioning recycled water consumption included irrigation $28.9 \mathrm{~L} / \mathrm{p} / \mathrm{d}$, toilet $27.5 \mathrm{~L} / \mathrm{p} / \mathrm{d}$ and leakage $2.7 \mathrm{~L} / \mathrm{p} / \mathrm{d}$. The pre-commissioning most likely end use estimates from Phase 1, included irrigation of $30.6 \mathrm{~L} / \mathrm{p} / \mathrm{d}$, toilet $21.7 \mathrm{~L} / \mathrm{p} / \mathrm{d}$ and leakage $0.7 \mathrm{~L} / \mathrm{p} / \mathrm{d}$. As seen in Figure A.4, a difference in post-commissioning end use was predicted for irrigation due to a likely change in demand instigated by the presence of recycled water, while toilets and leakage consumption was not altered. The pre-commissioning upper end use estimates included increased irrigation usage of $41.8 \mathrm{~L} / \mathrm{p} / \mathrm{d}$. When comparing recycled water end uses pre- and 
post-commissioning, recorded irrigation of $28.9 \mathrm{~L} / \mathrm{p} / \mathrm{d}$ (post-commissioning) was very close to the most likely estimate of $30.6 \mathrm{~L} / \mathrm{p} / \mathrm{d}$. The variation between the most likely prediction and actual post-commissioning end use is due to the increase in toilet and leakage use. This demonstrates that the indicators and methodology used to predict recycled water irrigation uptake post-commissioning was relatively accurate and provides rigour to the utilisation of this predictive model for recycled irrigation uptake. While, the differences between the Phase 1 recycled water uptake prediction and the Phase 2 actual recycled water consumption are not dramatically different, this variation does support the need to undertake data collection to verify predictions and assumptions. This data also allows for the strengthening and validation of the Phase 1 PC End Use Study recycled water uptake prediction model. Some alteration will need to be made to the predictive model to include an increase in consumption for both toilet and leakage coinciding with an increase in average daily demand.

\subsection{COMPILATION OF END USE AVERAGE HOURLY DIURNAL PATTERNS}

\subsection{Developed end use diurnal pattern software tool}

A software tool was developed to assimilate data files containing household end use water consumption events into patterns of average hourly use. The software was designed to read water usage events from analysed end use data files (interchangeable Trace Wizard/MSAccess) and collate the individual fixture use events into hourly usage periods across a day. The tabulated data can be grouped within user selected time periods, from hourly ( 24 graph points) through to five minute intervals (288 graph data points). This function enables the display of data to the resolution detail required within an average day 24 hour period. The software can collate single and/or multiple files as indicated by the user, in order to explore the determination of water usage from particular regions, suburbs or homes with a particular socioeconomic status or varying occupancy. The software outputs compiled data in the form 
of a spreadsheet and/or graph. As further elaborated below, end use diurnal patterns, which are premised on actual high resolution smart metering data for a particular region, provide essential information for a range of infrastructure planning functions.

\subsection{Diurnal patterns of consumption}

Average hourly water consumption patterns demonstrate daily water demand and peak usage throughout the day. Diurnal patterns were determined for both the single and dual reticulated regions for total household consumption along with the dual reticulated potable and recycled supply lines only (Figure A.5).

\section{[INSERT FIGURE A.5]}

Figure A.5 illustrates the variation in daily water demand between the single and dual reticulated regions. While total daily consumption was slightly higher in the dual reticulated region, the single reticulated regions maximum peak was greater than that seen in the dual reticulated region. Interestingly, the morning peak in the single reticulated region inclines sharply to just above 22 litres per hour per person per day $(\mathrm{L} / \mathrm{h} / \mathrm{p} / \mathrm{d})$ between 8 am and $9 \mathrm{am}$ (Figure A.5), while the dual reticulated morning peak (total supply) rises more gradually to reach a peak of just $16 \mathrm{~L} / \mathrm{h} / \mathrm{p} / \mathrm{d}$ at $8 \mathrm{am}$ (Figure A.5). This trend is reversed in the evening, with the dual reticulated region peaking at $19 \mathrm{~L} / \mathrm{h} / \mathrm{p} / \mathrm{d}$ at $7 \mathrm{pm}$ (total supply), while the single reticulated evening peak is much more gradual reaching $12 \mathrm{~L} / \mathrm{h} / \mathrm{p} / \mathrm{d}$ at $6 \mathrm{pm}$. The diurnal pattern for the single reticulated region is similar to the trend determined by Mead (2008) but differs to that found by Roberts (2005). The apparent variations in diurnal characteristics and peak demand between the supply regions (Figure A.5) illustrate the impact of varying sociodemographics and behaviours between the sample groups. When comparing the single 
reticulated region with the dual reticulated regions potable supply the morning peak ranges from $22 \mathrm{~L} / \mathrm{h} / \mathrm{p} / \mathrm{d}$ to just $12 \mathrm{~L} / \mathrm{h} / \mathrm{p} / \mathrm{d}$ while the evening peak flows are both at $12 \mathrm{~L} / \mathrm{h} / \mathrm{p} / \mathrm{d}$. This significant reduction in potable peak morning flow demonstrates the variation in potable demand that can exist between single and dual reticulated supply regions. To further explore the apparent differences in diurnal pattern between traditional single reticulated and dual reticulated regions, end use diurnal patterns were examined.

\subsection{End use diurnal patterns of consumption}

Daily end use consumption patterns allow for the determination of water use events that contribute to peak demands. Figure A.6 presents the diurnal patterns of the single reticulated region (Figure A.6a), dual reticulated region potable and recycled combined supply (Figure A.6b), dual reticulated potable only (Figure A.6c) and dual reticulated recycled line only (Figure A.6d).

\section{[INSERT FIGURE A.6]}

Figure A.6a demonstrates that in the single reticulated region the largest peak occurred between 8 and 9am with another small peak at $1 \mathrm{pm}$ and an evening peak at $6 \mathrm{pm}$. The sharp morning peak is predominantly due to showering and clothes washing. All other household end uses are also higher in this morning peak with the exception of leakage. Irrigation use appears to peak earlier in the morning than other end uses demonstrating an alignment with current water restrictions and awareness messages that encourage outdoor watering in early morning and late afternoon. Evening irrigation occurred between 5 to $7 \mathrm{pm}$. Leakage remains relatively consistent while dishwasher use occurred in the morning, after lunch and after dinner. Bath use peaked in the morning while, tap use was at its highest between 8 to $9 \mathrm{am}$ and 
6 to $8 \mathrm{pm}$. Toilet flushing was highest in the morning and relatively consistent throughout the day. Clothes washer use peaked in the morning between 7 and 9am and dropped drastically after $10 \mathrm{pm}$. In the single reticulated region shower use is the primary contributor to the morning peak while, evening peak usage was due to irrigation and shower end use.

The end use pattern of daily demand for the PC dual reticulated region total (Figure A.6b) exhibited distinctive differences when compared with the single reticulated region (Figure A.6a). Figure A.6b illustrates the morning peak at $8 \mathrm{am}$, with another small peak at $3 \mathrm{pm}$, while the greatest evening peak occurred between 6 to $8 \mathrm{pm}$. Leakage is much lower in the dual reticulated region and is generally present during the waking hours of the day. Dishwasher use peaks in the morning and evenings. Bath use peaks in the evenings, while tap usage had similar peaks in the morning and evenings with consistent use throughout the day. In PC (Figure A.6b), showering is the highest morning end use, as seen in the single reticulated region. Showering peaks at $8 \mathrm{am}$ and between 6 to $7 \mathrm{pm}$ in the evening. Clothes washer use also contributes to the morning peak between $8 \mathrm{am}$ to $10 \mathrm{am}$, slightly later than the single reticulated region. Irrigation on the potable line peaks at $3 \mathrm{pm}$ and again between 6 to $7 \mathrm{pm}$. On the recycled water supply line (Figure A.6b), leakage is highest between $10 \mathrm{am}$ and $12 \mathrm{pm}$ and remains relatively consistent across the rest of the day. Toilet use with recycled water is relatively even across the waking hours of the day with a slight peak in the morning and evening. Recycled water irrigation is higher between 2 to 4 am and inclines sharply in the evening between 6 to $8 \mathrm{pm}$ (Figure A.6b). Irrigation on the recycled line is the primary contributor of the high evening peak; shower use is the highest contributor to the morning peak (Figure A.6b). 


\subsection{Variation in peaks between single and dual reticulated supply schemes}

Dual supply regions introduce two separate reticulated supply sources to reduce the average daily and peak demand on potable supply systems as experienced in single reticulated regions. Figure A.6c and d present the diurnal demand experienced in the dual reticulated system on the potable and recycled water pipelines, respectively. When comparing the single reticulated regions diurnal demand (Figure A.6a) with the dual reticulated regions potable diurnal demand (Figure A.6c) a significant reduction in peak morning demand is apparent while, the evening demand remains relatively similar. The recycled water supply pipeline removes toilet flushing, some irrigation and leakage in both the morning and evening peaks. The recycled water supply reduces the peak morning demand by $4 \mathrm{~L} / \mathrm{h} / \mathrm{p} / \mathrm{d}$ and the evening peak by 10 $\mathrm{L} / \mathrm{h} / \mathrm{p} / \mathrm{d}$ in the dual reticulated region when looking at the combined potable and recycled water supply (Figure A.6b). This is a significant saving when considering the sizing of water supply infrastructure for peak demands. The use of recycled water for clothes washing (occurring in some dual reticulated regions in Australia) has the potential to reduce the peak morning demand by an additional $4 \mathrm{~L} / \mathrm{h} / \mathrm{p} / \mathrm{d}$. While, the diurnal patterns of demand do differ between the single and dual reticulated supply regions, the introduction of a recycled water supply network does reduce the average daily demand and peak demands when compared with traditional single reticulated supply. Understanding end use daily patterns of demand has significant application and implication for sustainable urban water planning and management.

\subsection{CONCLUSIONS, IMPLICATIONS AND FUTURE DIRECTIONS}

The results from this end use investigation provide much needed data for the verification of end use water consumption and daily demand patterns in single and dual reticulated water supply regions. This is a unique world first investigation predicting and measuring actual end use water consumption in a dual reticulated water supply region. The recycled water uptake, 
post-commissioning (Phase 2), was higher than initially predicted pre-commissioning (Phase 1) primarily due to increases in toilet and leakage consumption. The predictive model focussed on post-commissioning increases of irrigation which, resulted in the predicted versus actual recycled irrigation end use being very close. Post-commissioning of recycled water in the PC region resulted in this supply providing $59.1 \mathrm{~L} / \mathrm{p} / \mathrm{d}$ or $32.2 \%$ of total daily consumption. Of this, irrigation on the recycled water line was $28.9 \mathrm{~L} / \mathrm{p} / \mathrm{d}$ or $15.7 \%$ of total daily consumption compared to the predicted most likely uptake of $30.6 \mathrm{~L} / \mathrm{p} / \mathrm{d}$. Understanding the baseline recycled water consumption, and the variation in irrigation and other end uses through high and low demand periods from climatic conditions, provides data to assist in predicting and modelling yearly demand and supply for potable and recycled water infrastructure in dual reticulated regions. This also applies to single reticulated regions.

Validating the daily diurnal patterns for both single and dual reticulated regions demonstrates maximum and average demands in these supply schemes and identifies the end uses which attribute to peaks. Such data is invaluable for modelling and forecasting demand and supply and for verification of assumptions in desired standards of service and other water services infrastructure planning documentation. The end use diurnal patterns determined for the PC region provides support for the implementation of dual reticulated supply schemes as they can provide significant reductions in peak demands on potable water infrastructure. The potable water demand peaked at $12 \mathrm{~L} / \mathrm{p} / \mathrm{h} / \mathrm{d}$ in the dual reticulated region compared with $22 \mathrm{~L} / \mathrm{p} / \mathrm{h} / \mathrm{d}$ in the single reticulated region. Such significant reductions in peak demand would allow for reductions in pipe sizing and treatment volumes of potable water for this region.

The collected end use data from the PC End Use Study will inform the sizing of infrastructure, can assist in delaying infrastructure upgrades and also validating and directing 
water treatment and pumping requirements of potable and recycled water to regions in the Gold Coast, Australia. Understanding recycled water demand also allows for accurate forecasting of recycled water discharges for the environment. The data also provides verification of the assumptions made in the PCWF Master Plan for recycled and potable water consumption and savings. Data can also be used to inform the development of demand management messages to offset peak usage periods i.e. encouraging showering in later hours of the day when possible and to encourage PC residents to use recycled water almost exclusively for external irrigation.

Overall, the results from this study support the application of dual reticulated schemes through significant reductions in peak demand on potable water supply infrastructure and by the reduction of average potable water demand by $59.1 \mathrm{~L} / \mathrm{p} / \mathrm{d}$ or $32.2 \%$. The diurnal patterns of daily demand differ extensively between the single and dual reticulated regions demonstrating the unique consumption patterns in these alternative supply schemes. Information gathered through this study will assist in the refinement of predictions and assumptions for both end use and diurnal demands for single and dual reticulated regions water infrastructure planning. It will allow for accurate forecasting and modelling resulting in informed decision making for water infrastructure sizing and upgrades and future supply and demand requirements in the Gold Coast.

\section{REFERENCES}

ABS (2010) Australia's Environment: Issues and Trends 2010. Australian Bureau of Statistics, Canberra.

American Water Works Association (1999) Residential End Uses of Water. Aquacraft, Inc. Water Engineering and Management, Denver, CO. 
Anderson, J. M. (1996) The potential for water recycling in Australia: Expanding our horizons. Desalination, Vol 106:1-3, pp. 151-156.

Barlow, M. (2009) Notes for Opening Keynote Australian Water Summit, 1 April 2009. Australian Water Summit.

Birrell, B., Rapson, V. \& Smith, F. (2005) Impact of Demographic Change and Urban Consolidation on Domestic Water Use. Water Services Association of Australia Inc, Melbourne.

Commonwealth of Australia (2008a) Drought. online article, available at http://www.bom.gov.au/lam/climate/levelthree/c20thc/drought.htm Accessed 20/03/08. Bureau of Meteorology.

Commonwealth of Australia (2008b) Living with Drought. online article, available at http://www.bom.gov.au/climate/drought/livedrought.shtml Accessed 14/03/08. Bureau of Meteorology.

Commonwealth of Australia (2010) Australian Climate Change and Variability. Online article, available: http://www.bom.gov.au/climate/change/aus cvac.shtml. Bureau of Meteorology.

DNRM (2005) Planning Guidelines for Water Supply and Sewerage. Department of Natural Resources and Mines.

Fearnley, E. J., Thomas, K. D., Luscombe, A. \& Cromar, N. (2004) Determination of water usage rates and water usage patterns in residential recycling initiative in South Australia. Environmental Health, Vol 4:2, pp. 72-81.

Gato, S. (2006) Forecasting Urban Residential Water Demand. School of Civil, Environmental and Chemical Engineering. RMIT, Melbourne.

GCW (2004) Pimpama Coomera Waterfuture Master Plan March 2004. Gold Coast, Gold Coast Water and Gold Coast City Council.

GCW \& GCCC (2007) The Gold Coast Waterfuture Strategy 2006-2056. Gold Coast, Gold Coast Water and Gold Coast City Council

Giurco, D., Carrard, N., McFallan, S., Nalbantoglu, M., Inman, M., Thornton, N. \& White, S. (2008a) Residential end-use measurement guidebook: a guide to study design, sampling and technology. Prepared by the Institute for Sustainable Futures, UTS and CSIRO for the Smart Water Fund, Victoria.

Giurco, D., Carrard, N., Wang, Z., Inman, M. \& Nguyen, M. (2008b) Innovative smart metering technology and its role in end-use measurement. Water Efficiency 2008. Gold Coast.

Heinrich, M. (2007) Water End Use and Efficiency Project (WEEP) - Final Report. BRANZ Study Report 159. Judgeford, New Zealand, Branz.

Hurlimann, A. \& McKay, J. (2006) Urban Australians using recycled water for domestic non-potable use-An evaluation of the attributes price, saltiness, colour and odour using conjoint analysis. Journal of Environmental Management, Vol: 83, pp. 93-104.

Inman, D. \& Jeffrey, P. (2006) A review of residential water conservation tool performance and influences on implementation effectiveness. Urban Water Journal, Vol 3:3, pp. 127-143.

Loh, M. \& Coghlan, P. (2003) Domestic Water Use Study. Perth, Water Corporation. 
Marks, J. S. \& Zadoroznyj, M. (2005) Managing Sustainable Urban Water Reuse: Structural Context and Cultures of Trust. Society \& Natural Resources, Vol 18:6, pp. 557-572.

Mayer, P., DeOreo, W., Towler, E., Martien, L. \& Lewis, D. (2004) Tampa Water Department residential water conservation study: The impacts of high efficiency plumbing fixture retrofits in single-family homes. Aquacraft, Inc Water Engineering and Management, Tampa.

Mead, N. (2008) Investigation of Domestic End Use. Faculty of Engineering \& Surveying. The University of Southern Queensland, Toowoomba.

Mitchell, V. G. (2006) Applying Integrated Urban Water Management Concepts: A Review of Australia Experience. Journal of Environmental Management, Vol. 37:5, pp. 589-605.

Po, M., Nancarrow, B. E., Leviston, Z., Porter, N. B., Syme, G. J. \& Kaercher, J. D. (2005) Predicting Community Behaviour in Relation to Wastewater Reuse. CSIRO, Canberra.

Roberts, P. (2005) Yarra Valley Water 2004 Residential End Use Measurement Study. Melbourne, Yarra Valley Water.

Stewart, R.A., Willis, R.M., Giurco, D. Panuwatwanich, K. Capati, G. (2010) Web-based knowledge management system: linking smart metering to the future of urban water planning. Australian Planner, Vol. 47:2, pp. 66-74

Sydney Water (2008) Recycled water in the Rouse Hill area - saving drinking water for drinking. Online article, accessed 10/03/08. Available at: http://www.sydneywater.com.au/Publications/FactSheets/FINAL_Rouse_Hill_Brochure_Feb 08.pdf\#Page=1.

Turner, A. \& White, S. (2006) Does demand management work over the long term? What are the critical success factors? Sustainable Water in the Urban Environment II Conference.

Turner, A., White, S., Beatty, K. \& Gregory, A. (2005) Results of the largest residential demand management program in Australia. Institute for Sustainable Futures, University of Technology. Sydney Water Corporation, Sydney, NSW

Turner, A., White, S., Kazaglis, A. \& Simard, S. (2007) Have we achieved the savings? The importance of evaluations when implementing demand management. Water Science and Technology: Water Supply, Vol 7:5-6, pp. 203-210.

Webb, T. (2007) Towards Sustainable Water Futures in Western Sydney. In the pipeline: a symposium - new directions in cultural research on water. University of Western Sydney, NSW, Sydney.

White, S. (2001) Demand Management and Integrated Resource Planning in Australia. Efficient Use and Management of Water for Urban Supply. Madrid.

White, S. \& Turner, A. (2003) The role of effluent reuse in sustainable urban water systems: untapped opportunities. National Water Recycling in Australia Conference. Brisbane, September 2003.

Willis, R., Stewart, R. \& Emmonds, S. (2010a) Pimpama-Coomera dual reticulation end use study: pre-commission baseline, context and post-commission end use prediction. IWA Water, Science and Technology: Water Supply, Vol 10:3, pp. 302-314, DOI: 10.2166/ws.2010.104.

Willis, R., Stewart, R., Panuwatwanich, K., Capati, B. \& Giurco, D. (2009) Gold Coast Domestic Water End Use Study. Journal of Australian Water Association Vol 36:6, pp. 79-85. 
Willis, R. M., Stewart, R. A., Panuwatwanich, K., Jones, S. \& Kyrakides, A. (2010b) Alarming visual display monitors affecting shower end use water and energy conservation in Australian residential households. Journal of Resources, Conservation and Recycling, Vol 54:12, pp. 1117-1127, doi:10.1016/j.resconrec.2010.03.004.

WSAA (2003) Urban Water Demand Forecasting and Demand Management: research needs review and recommendations. White, S. Robertson, J. Cordell, D. Jha, M. Milne, G. Institute for Sustainable Futures UTS for Water Services Association, Sydney.

WSAA (2008) Guide to Demand Management. Water Services Association Australia and Institute for Sustainable Futures, Sydney.

Zhou, S. L., McMahon, T. A., Walton, A. \& Lewis, J. (2002) Forecasting operational demand for an urban water supply zone. Journal of Hydrology, 259, 189-202. 


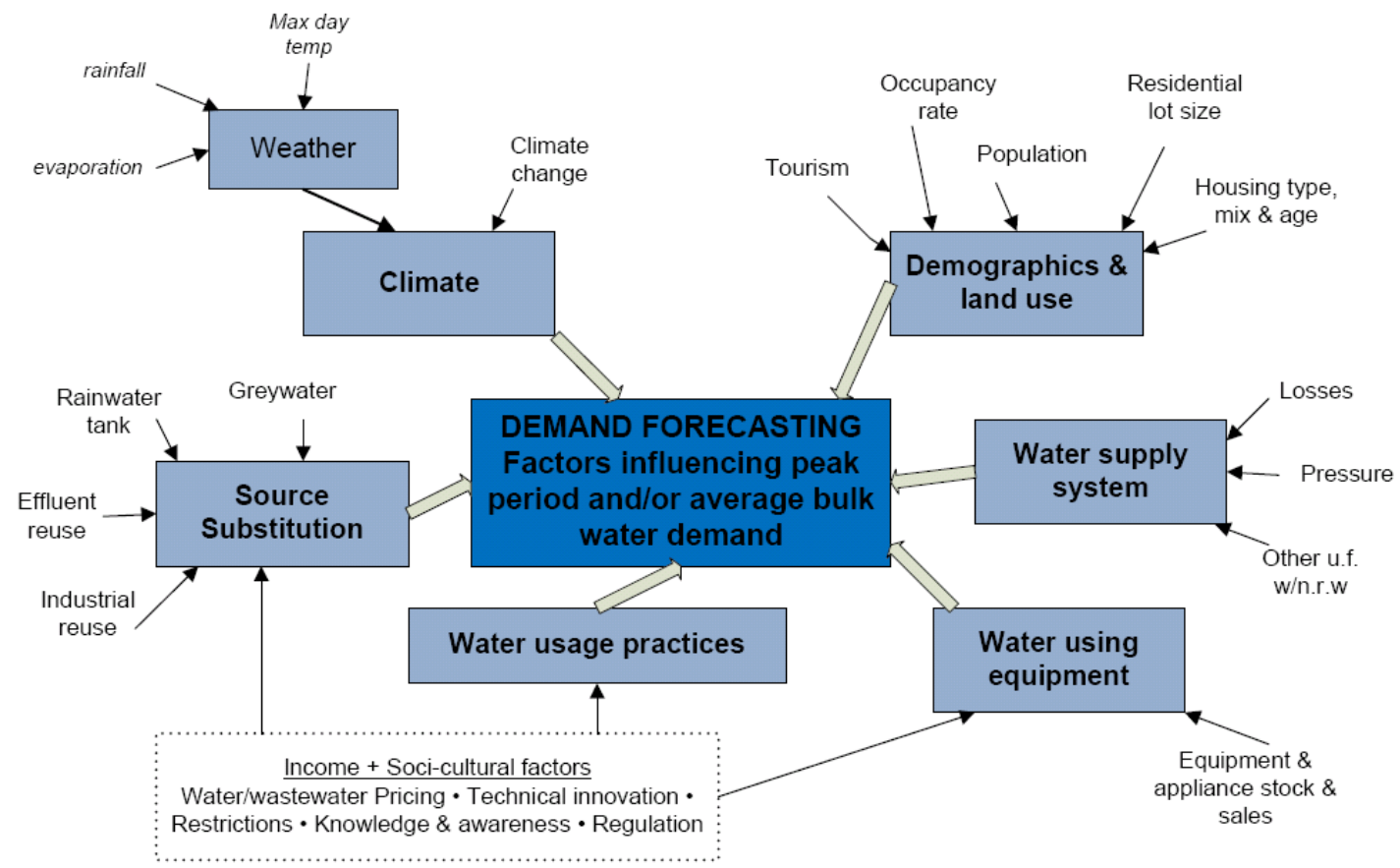

Figure A.1 Factors that influence demand (adapted from White and Turner (2003) \& WSAA (2008)) 
Table A.1 Summary of findings from other water end use studies

\begin{tabular}{|c|c|c|c|c|c|c|}
\hline Author & Study title & Country & Region & $\begin{array}{l}\text { No. } \\
\text { homes }\end{array}$ & $\begin{array}{l}\text { Avg. consumption } \\
\text { (L/p/day) }\end{array}$ & $\begin{array}{l}\text { End use or } \\
\text { additional } \\
\text { factors } \\
\text { investigated }\end{array}$ \\
\hline $\begin{array}{l}\text { Willis et } \\
\text { al. (2009) }\end{array}$ & $\begin{array}{l}\text { Gold Coast } \\
\text { Watersaver End } \\
\text { Use Study }\end{array}$ & Australia & Gold Coast & 151 & $\begin{array}{l}\text { Winter: } \\
\text { Indoor = } 138.6 \\
\text { Outdoor = } 18.6\end{array}$ & $\begin{array}{l}\text { End use only } \\
\text { to date }\end{array}$ \\
\hline $\begin{array}{l}\text { Mead } \\
(2008)\end{array}$ & $\begin{array}{l}\text { Investigation of } \\
\text { Domestic End } \\
\text { Use }\end{array}$ & Australia & Toowoomba & 10 & $\begin{array}{l}\text { Indoor \& outdoor } \\
=122\end{array}$ & $\begin{array}{l}\text { End use \& } \\
\text { diurnal } \\
\text { patterns }\end{array}$ \\
\hline $\begin{array}{l}\text { Heinrich } \\
\text { (2007) }\end{array}$ & $\begin{array}{l}\text { Water End Use } \\
\text { and Efficiency } \\
\text { Project (WEEP) }\end{array}$ & $\begin{array}{l}\text { New } \\
\text { Zealand }\end{array}$ & Kapiti Coast & 12 & $\begin{array}{l}\text { Indoor \& outdoor } \\
=184.2 \\
\text { Summer: } 203.9 \\
\text { Winter: } 168.1\end{array}$ & $\begin{array}{l}\text { End use \& } \\
\text { bulk diurnal } \\
\text { patterns }\end{array}$ \\
\hline $\begin{array}{l}\text { Roberts } \\
\text { (2005) }\end{array}$ & REUMS & Australia & $\begin{array}{l}\text { Yarra Valley, } \\
\text { Melbourne }\end{array}$ & 100 & $\begin{array}{l}\text { Indoor }=169 \\
\text { Outdoor = extra } \\
20 \%=34\end{array}$ & $\begin{array}{l}\text { End use \& } \\
\text { diurnal } \\
\text { patterns }\end{array}$ \\
\hline $\begin{array}{l}\text { Mayer et } \\
\text { al. (2004) }\end{array}$ & $\begin{array}{l}\text { Tampa Water } \\
\text { Department } \\
\text { Residential } \\
\text { Water } \\
\text { Conservation } \\
\text { Study }\end{array}$ & $\begin{array}{l}\text { United } \\
\text { States of } \\
\text { America }\end{array}$ & Tampa & 26 & $\begin{array}{l}\text { Pre retrofit }=752.9 \\
\text { Post retrofit }= \\
403.9 \\
\text { (indoor \& outdoor) }\end{array}$ & $\begin{array}{l}\text { End use and } \\
\text { retrofitting }\end{array}$ \\
\hline $\begin{array}{l}\text { Loh } \\
(2003)\end{array}$ & $\begin{array}{l}\text { Domestic Water } \\
\text { Use Study }\end{array}$ & Australia & Perth & $\begin{array}{l}124 \& \\
120\end{array}$ & $\begin{array}{l}\text { Indoor }=155 \\
\text { Outdoor }=\text { extra } \\
54 \%=83.7\end{array}$ & $\begin{array}{l}\text { End use \& } \\
\text { bulk diurnal } \\
\text { patterns }\end{array}$ \\
\hline $\begin{array}{l}\text { AWWA } \\
\text { (1999) }\end{array}$ & $\begin{array}{l}\text { Residential End } \\
\text { Uses of Water } \\
\text { (REUW) }\end{array}$ & $\begin{array}{l}\text { United } \\
\text { States of } \\
\text { America }\end{array}$ & 12 regions & 1188 & $\begin{array}{l}\text { Indoor }=262.3 \\
\text { Indoor \& outdoor } \\
=650.3\end{array}$ & $\begin{array}{l}\text { End use \& } \\
\text { diurnal } \\
\text { patterns }\end{array}$ \\
\hline
\end{tabular}




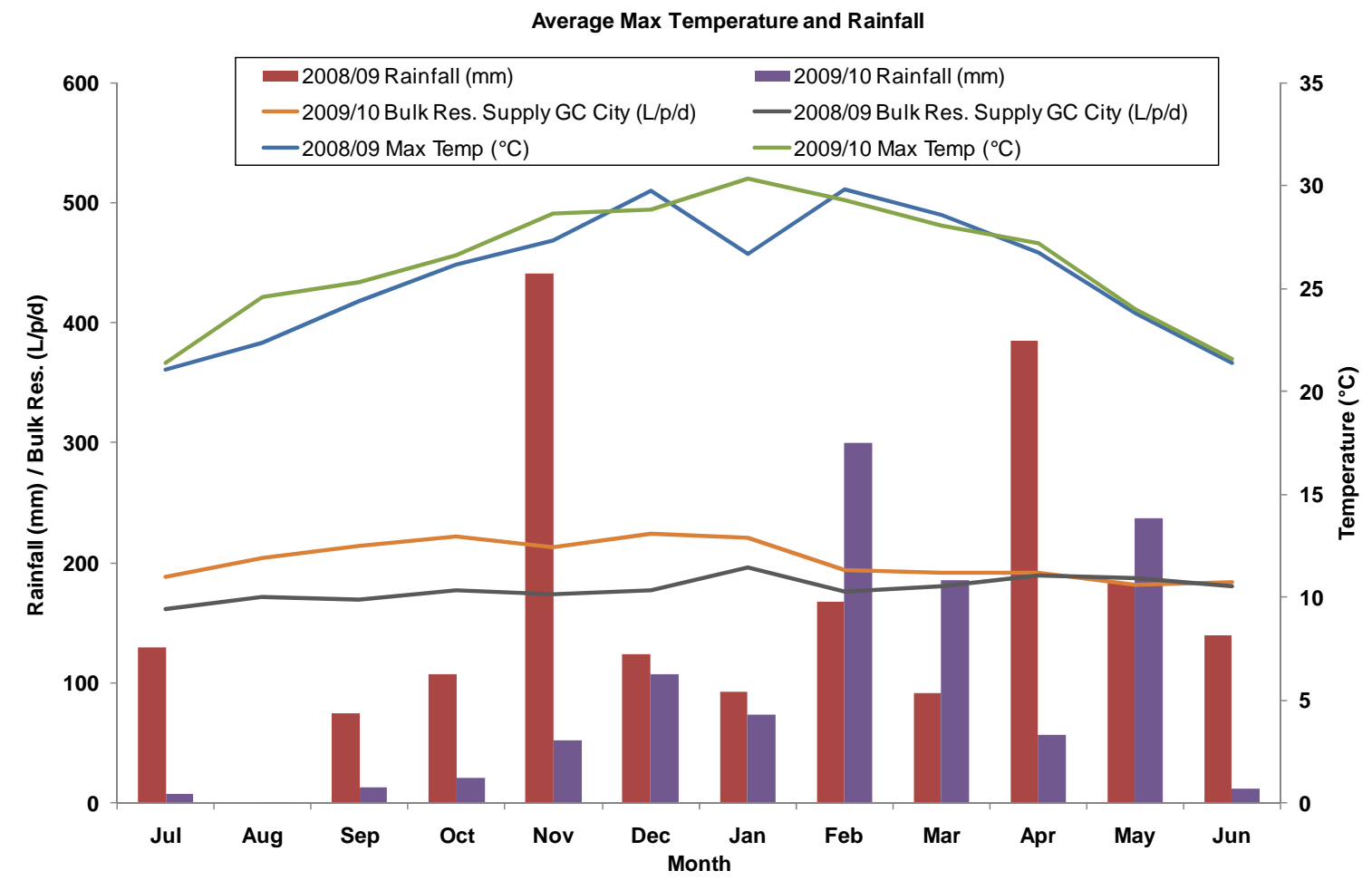

Figure A.2 Rainfall and maximum temperature with bulk recorded supply for Gold Coast City over the duration of the Gold Coast Watersaver End Use study July 2008 - June 2010

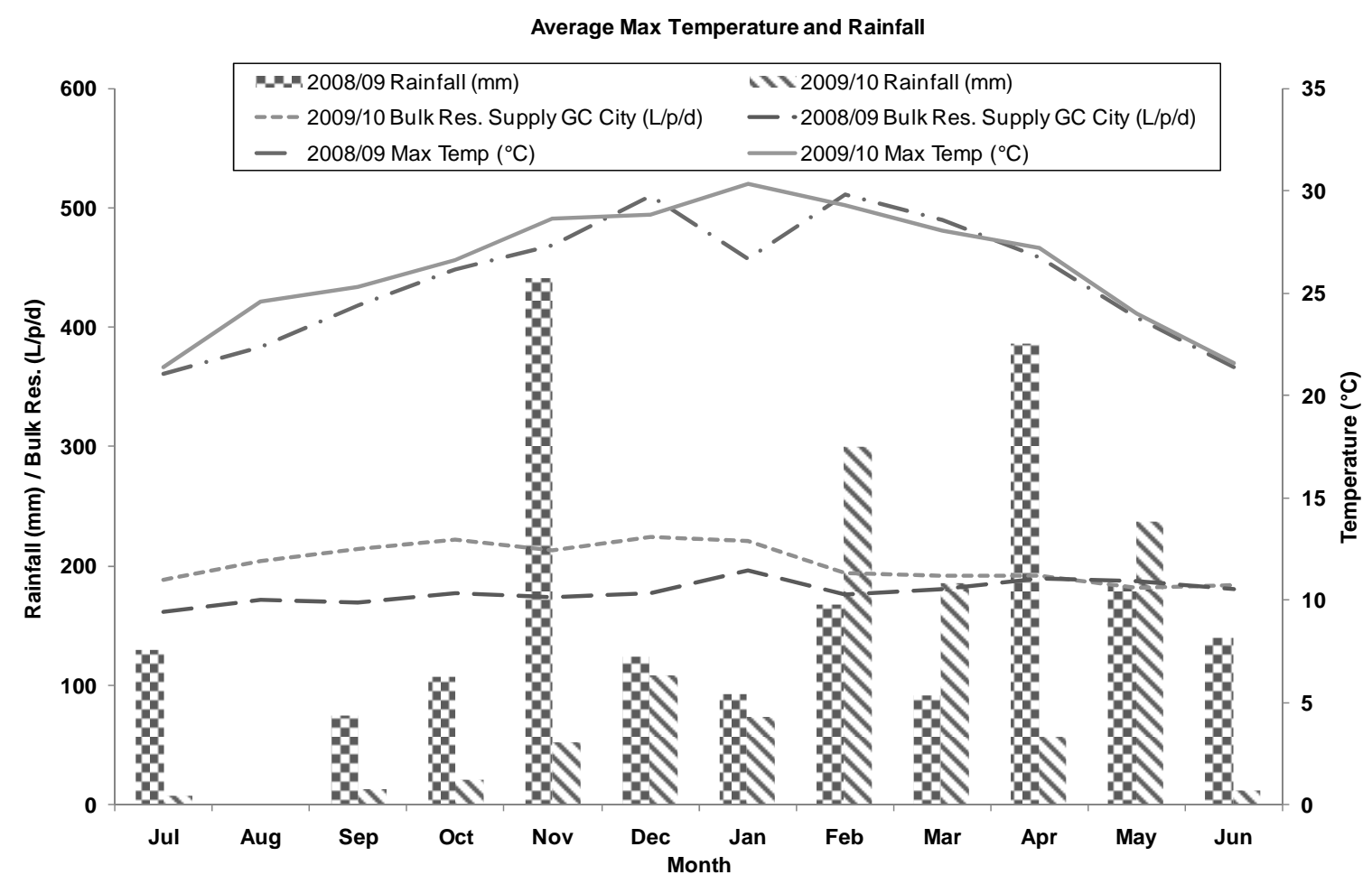




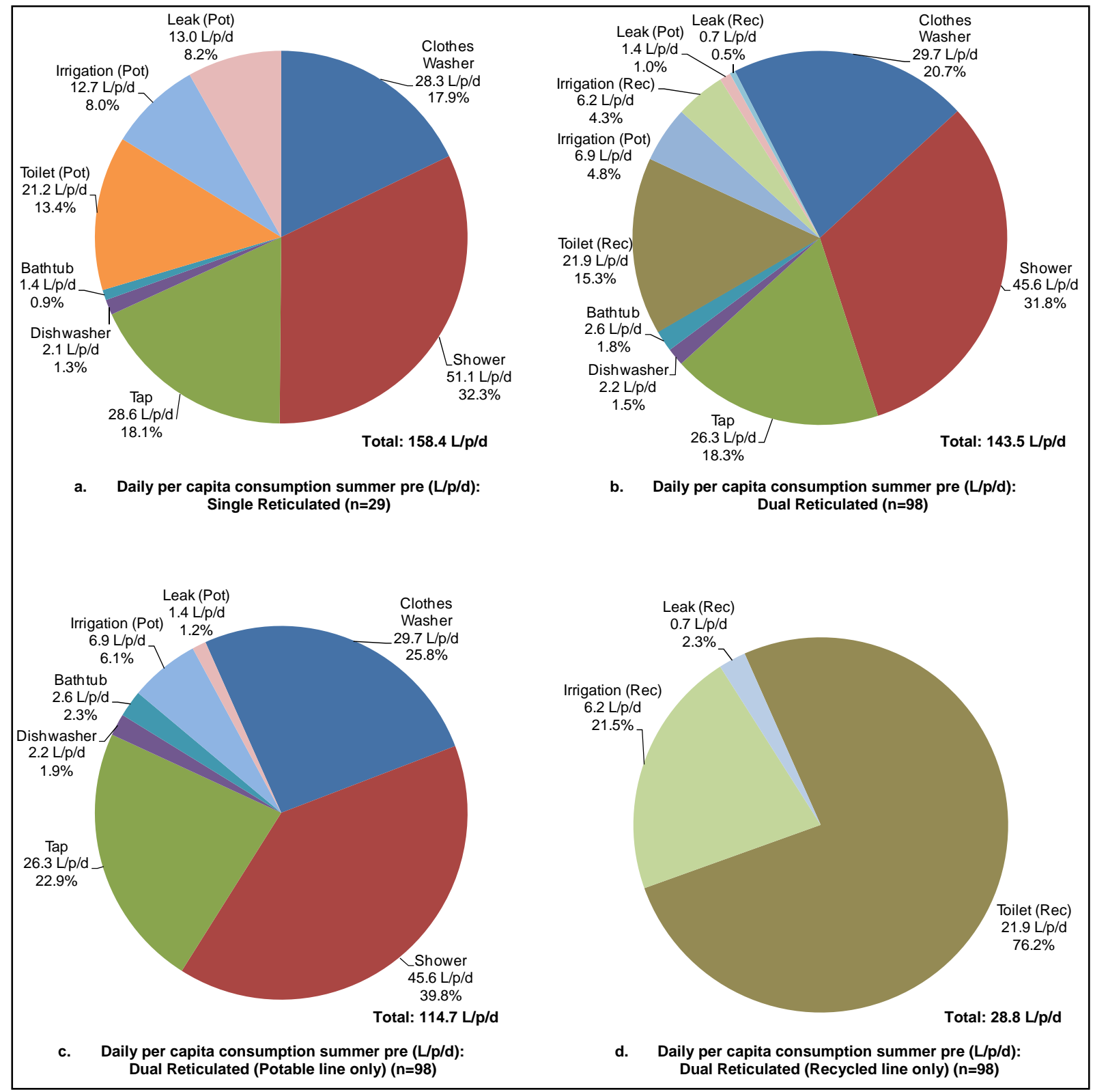

Figure A.3 Pre-commissioning end use water consumption data (summer 08/09) 


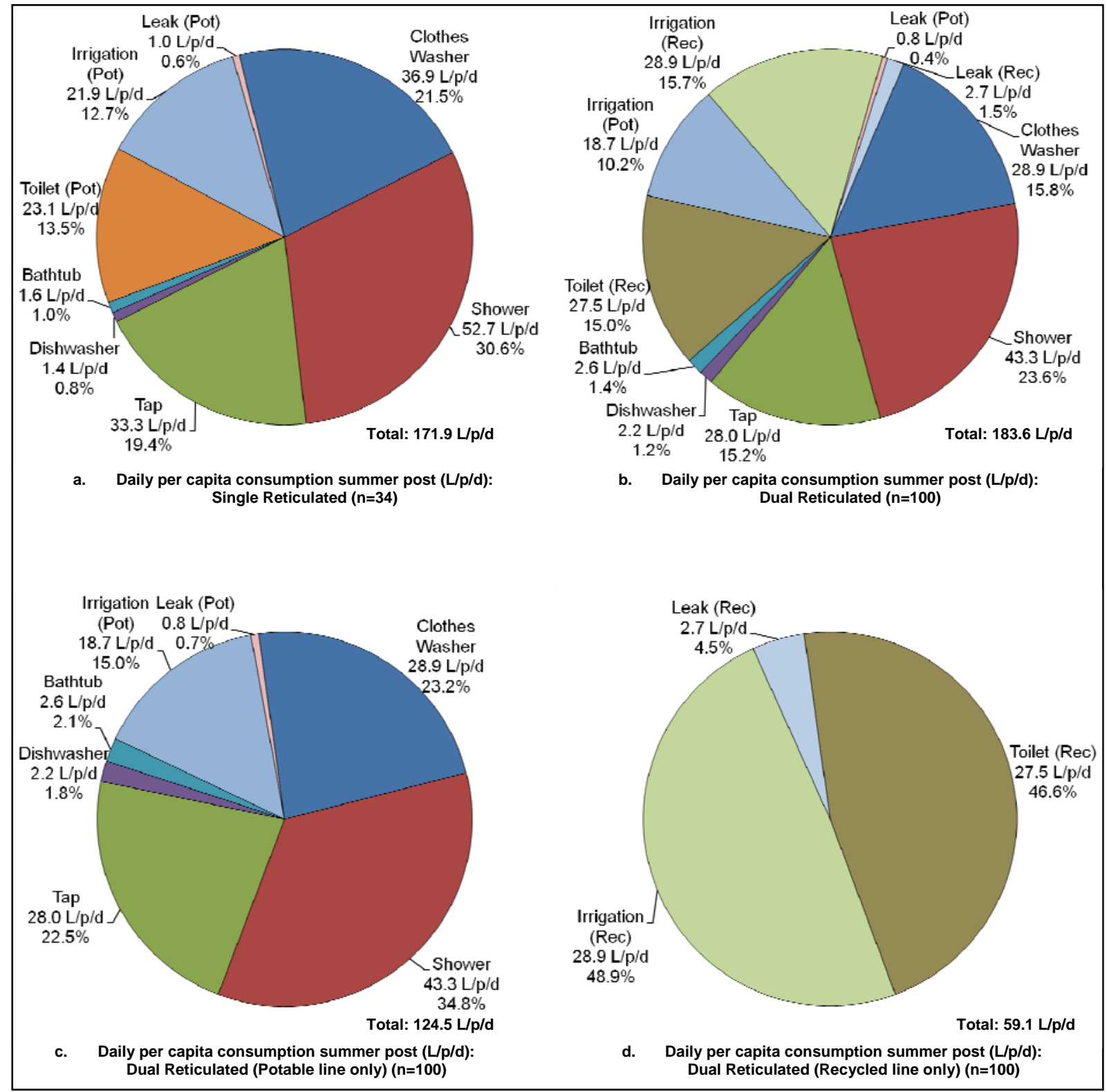

Figure A.4 Post-commissioning end use water consumption data (summer 09/10) 


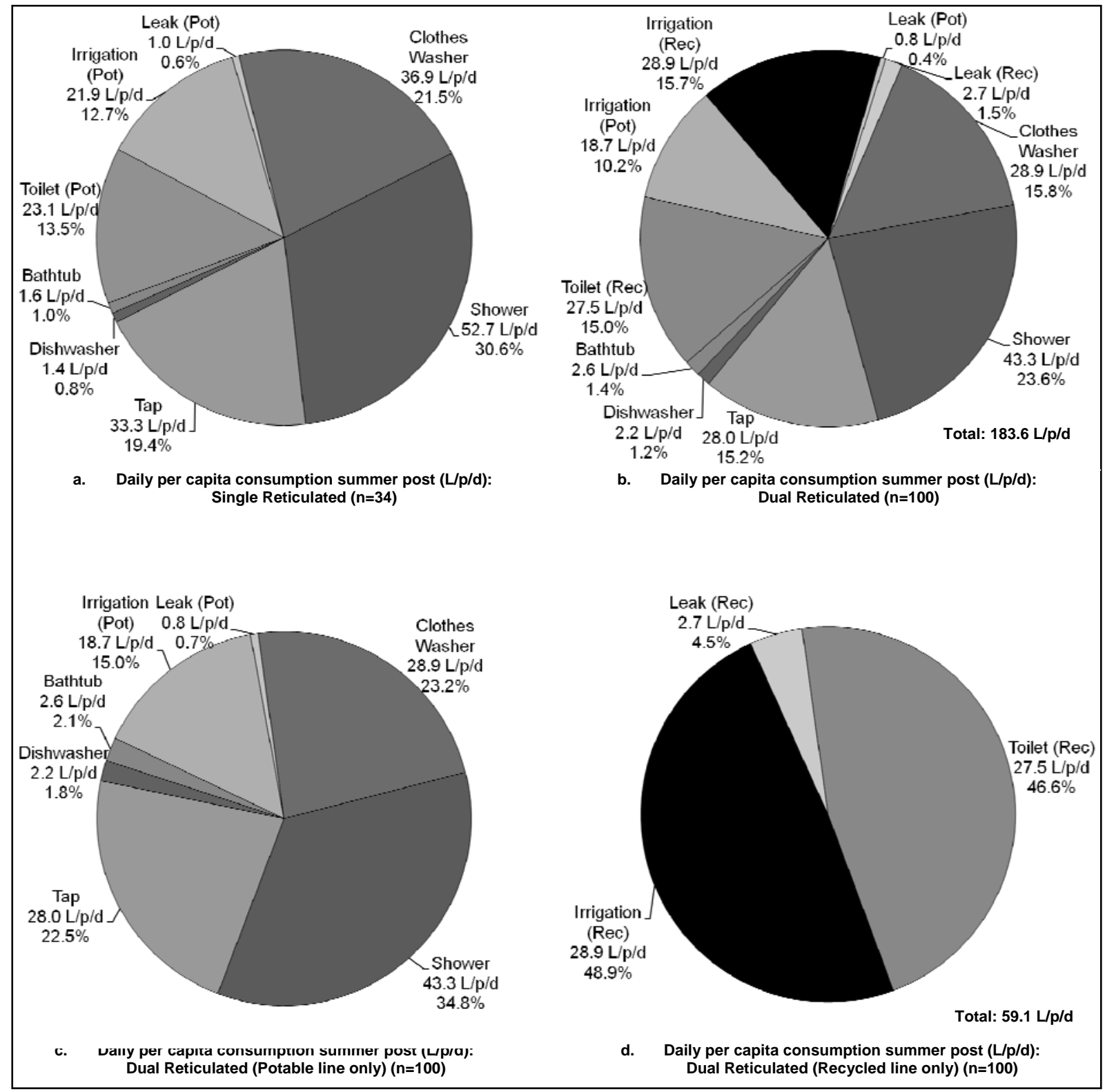

Figure A.4 Post-commissioning end use water consumption data (summer 09/10) 


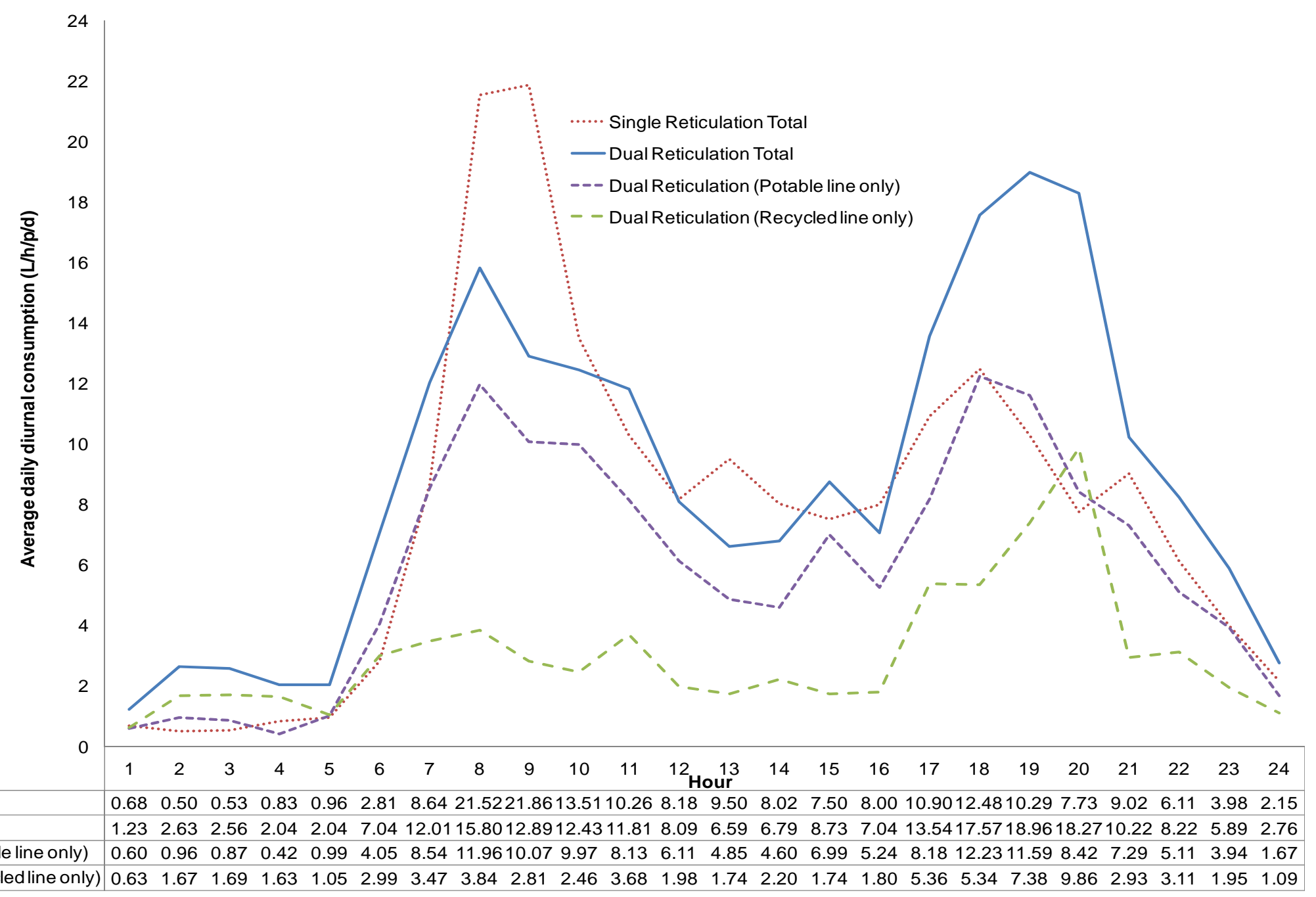

Figure A.5 Average hourly diurnal pattern profile: single and dual reticulated region 


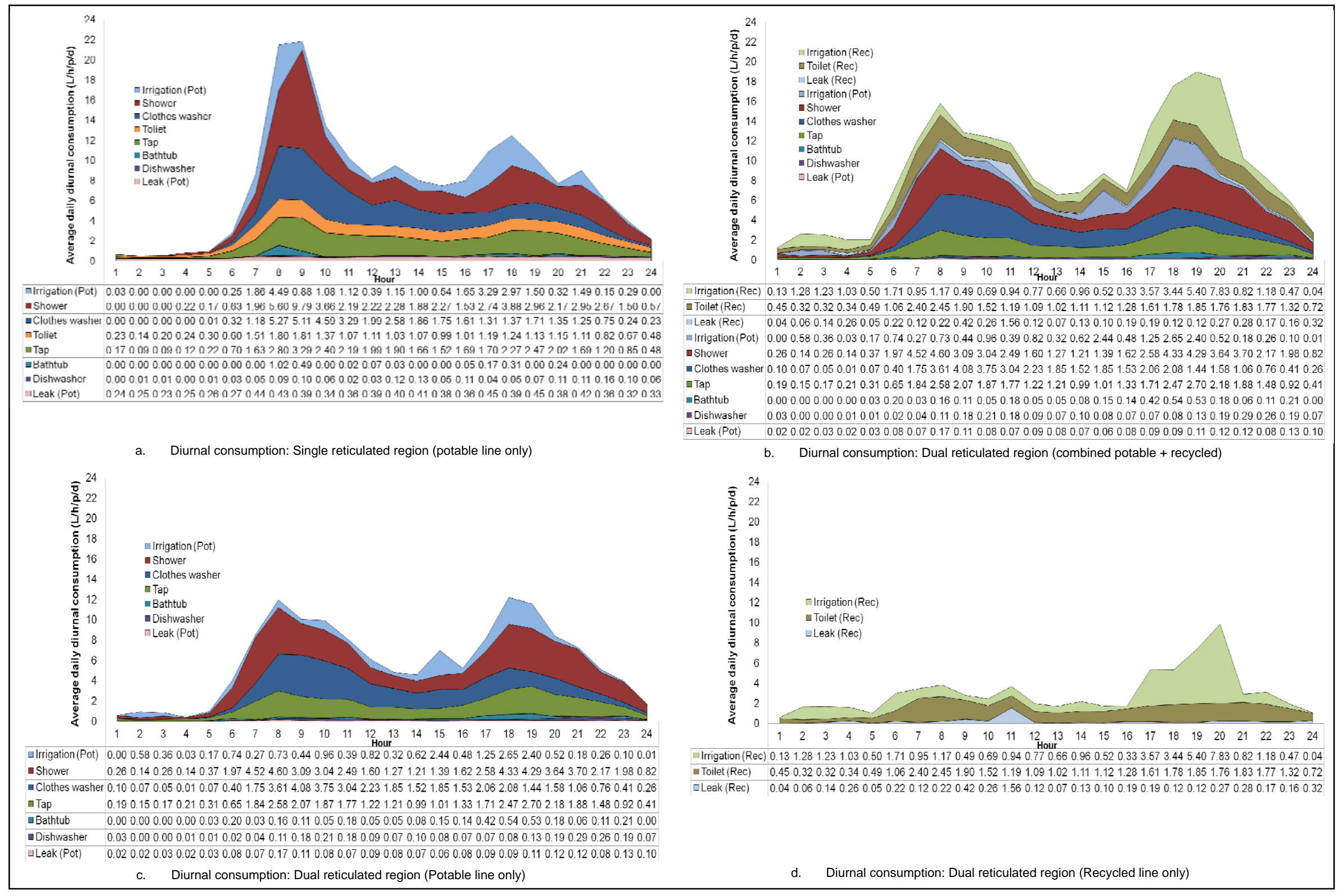

Figure A.6 End use hourly diurnal pattern profile: single and dual reticulated regions 